Images in...

\title{
Can a perianal condyloma reach the pelvis?
}

\author{
Pedro Mendes-Bastos, ${ }^{1}$ Vera Bernardino, ${ }^{2}$ Celia Coelho Henriques ${ }^{2}$ \\ 1Department of Dermatology and Venereology, Curry Cabral's Hospital, Lisbon, Portugal; \\ ${ }^{2}$ Department of Internal Medicine 2, Curry Cabral's Hospital, Lisbon, Portugal
}

Correspondence to Dr Celia Coelho Henriques, celia.c.henriques@gmail.com

\section{DESCRIPTION}

A 42-year-old MSM black male was admitted due to vigorous perianal bleeding. Physical examination revealed a $14 \times 8 \mathrm{~cm}$ exophytic erythematous perianal tumour with a moist verrucous surface (figure 1 , right). The lesion had its origin on the right anal verge, extending over $3 \mathrm{~cm}$ on the anal canal, as seen by anuscopy. There was no locoregional lymphadenopathy upon palpation. Laboratory data revealed microcytic anaemia $(\mathrm{Hg} 3.9 \mathrm{~g} / \mathrm{dl})$ and pelvic MRI showed abnormalities on the external anal sphincter, right isquiorectal fossa fat and thickening of perianal skin. On histopathology, there was a papillomatous epithelial proliferation with viral cytopathic effect and no signs of atypia, in keeping with condyloma acuminatum (figure 2). Patient's history was remarkable for a 4-year HIV-1 positive serology (current viral load $<50$ copies $/ \mathrm{ml}$ and CD $4+$ count 123 cells $/ \mathrm{mm}^{3}$ ), diabetes mellitus and chronic renal disease. He was on highly active antiretroviral therapy, insulinotherapy and dialysis. He had had a sexually transmitted diseases appointment 2 years before (figure 1, left) and refused surgical treatment. In face of the presumptive diagnosis of Buschke-Löwenstein tumour, a wide local surgical excision was planned. The patient unexpectedly died during the anaesthetic induction. Buschke-Löwenstein tumour or giant condyloma acuminatum is considered a verrucous carcinoma, being locally invasive, but rarely capable of metastatic disease. It is an uncommon tumour of the anorectum, associated with the human papillomavirus types $6 / 11$.
Though foci of squamous cell carcinoma are commonly found, its histology may look remarkably benign; thus, the lack of a wider sample does not allow to rule out a malignant transformation in this case. Radical surgery can be curative, but recurrences are frequent. ${ }^{12}$

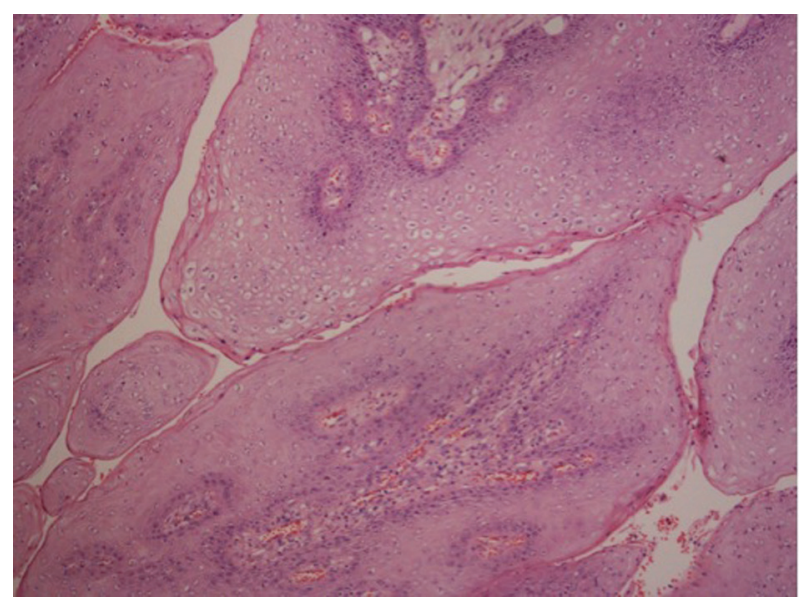

Figure 2 Buschke-Lowenstein tumour sample on microscopy (H\&E). Notice the parakeratosis, granular vacuolisation and hyperkeratosis with a thick stratum corneum in the specimen analysed; these features generally characterise the benign $\mathrm{BL}$ tumours and support the differential diagnosis from ordinary warts.
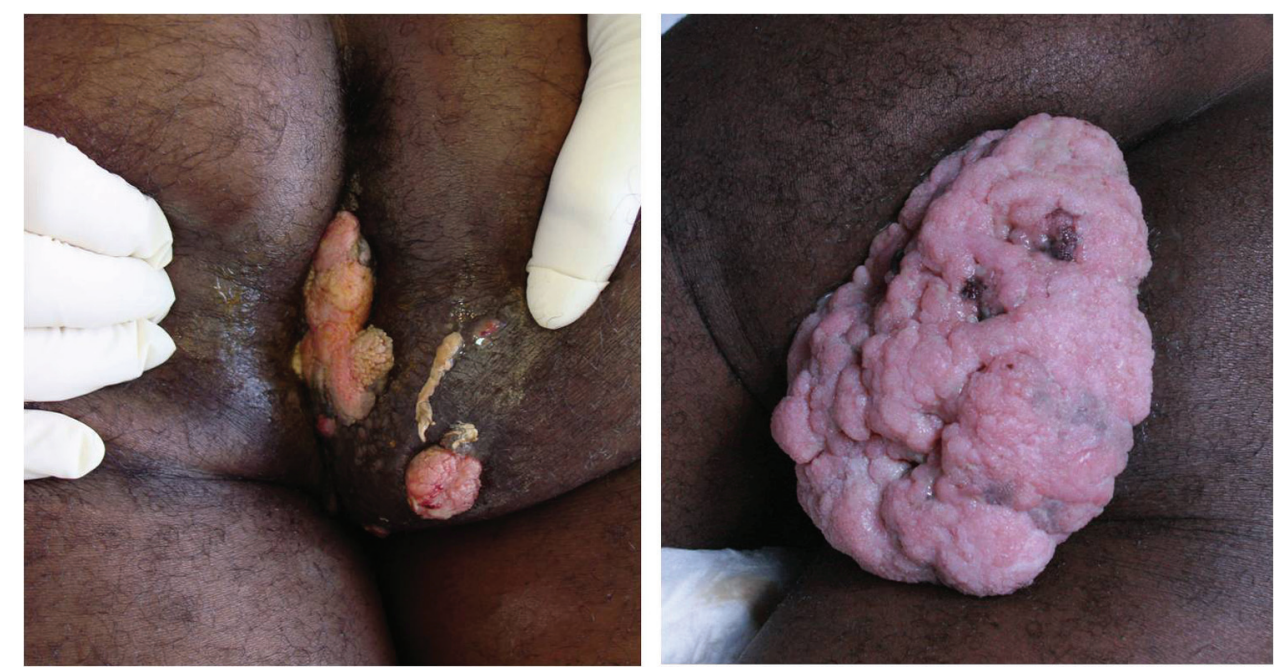

Figure 1 Patient's perianal lesion on a sexually transmitted diseases appointment in 2009 and on admission, 2011. 


\section{BMJ Case Reports}

\section{Learning points}

- Patients with condylomata acuminata must be treated in an early stage of disease.

- Buschke-Löwenstein tumour should be aggressively managed due to its high morbidity and possible complications.
Competing interests None.

Patient consent Obtained.

\section{REFERENCES}

1. Kirnbauer R, Lenz P, Okun MM. Human Papillomavirus. In Bolognia JL, Jorizzo JL, Rapini RR, Callen JP, Horn TD, Mancini AN,eds. Dermatology. Second Edition. Lisbon: Mosby Elsevier 2008:1183-98.

2. Trombetta LJ, Place RJ. Giant condyloma acuminatum of the anorectum: trends in epidemiology and management: report of a case and review of the literature. Dis Colon Rectum 2001;44:1878-86.

This pdf has been created automatically from the final edited text and images.

Copyright 2012 BMJ Publishing Group. All rights reserved. For permission to reuse any of this content visit http://group.bmj.com/group/rights-licensing/permissions.

BMJ Case Report Fellows may re-use this article for personal use and teaching without any further permission.

Please cite this article as follows (you will need to access the article online to obtain the date of publication).

Mendes-Bastos P, Bernardino V, Henriques CC. Can a perianal condyloma reach the pelvis?

BMJ Case Reports 2012;10.1136/bcr-2012-006241, Published XXX

Become a Fellow of BMJ Case Reports today and you can:

- Submit as many cases as you like

- Enjoy fast sympathetic peer review and rapid publication of accepted articles

- Access all the published articles

- Re-use any of the published material for personal use and teaching without further permission

For information on Institutional Fellowships contact consortiasales@bmjgroup.com

Visit casereports.bmj.com for more articles like this and to become a Fellow

Keep up to date with all published cases by signing up for an alert (all we need is your email address) http://casereports.bmj.com/cgi/alerts/etoc 